\title{
Pattern and problem of poultry consumption by the rural and urban families of Fulbaria Upazila
}

\author{
M.A. $\mathrm{Hai}^{1}$, M. Mahiuddin, M.A.R. Howlider and T. Yeasmin ${ }^{2}$ \\ Department of Poultry Science, Bangladesh Agricultural University, Mymensingh-2202, \\ ${ }^{1}$ Department of Livestock Services, Farmgate, Dhaka and ${ }^{2}$ Department of Veterinary and Animal \\ Science, Hazee Mohammad Danesh Science and Technology University, Dinajpur-5200, Bangladesh
}

\begin{abstract}
The pattern and problem of poultry consumption by the rural and urban families of Fulbaria upazilla were studied. Data were collected through interview schedule from 100 respondents (50 from rural area and 50 from urban area). Problem confrontation index $(\mathrm{PCl})$ in urban area 27 to 143 against the possible range of 0 to 150 and in rural area 33 to 138 against the possible 0 to 150 . Overall area $\mathrm{PCl}$ was 60 to 281 against the possible range of 0 to 300. Nonavailability of day old chicks, lack of optimum amount of feed, unbalanced diets and fluctuating prices of eggs and meat were the acute problems hampered the consumption of poultry. The average farm size in urban and rural areas was 167.84 and 233.94 decimal. Livestock population consisted of $80 \%$ poultry and $20 \%$ large animal. Poultry contributed $4 \%$ of the total income in the rural area and $3 \%$ in the urban area. Rural people have less knowledge on health and nutrition than that of urban people. Poultry consumption in both rural and urban area is certainly very low. A positive correlation of age with poultry consumption implies that per capita poultry consumption is higher for older people. Reverse case is expected to build a healthy society. From correlations it can be concluded that in urban area increased farm size, increased livestock population, increased income, better knowledge on health and nutrition and decreased family size should increase per capita poultry consumption. Correlations also indicate that decreased family size and better knowledge on health and nutrition could minimize problems of poultry consumption. In rural area correlations computed impress that increased literacy, increased farm size, increased livestock population, increased income and better knowledge on health and nutrition should increase per capita poultry consumption. Whereas, increased income could remove problems of poultry consumption.
\end{abstract}

Keywords: Poultry, Consumption, Problem confrontation index, Pattern and problem

\section{Introduction}

Poultry meat and egg production is an efficient way to bridge nutritional gap at a faster rate. Consumers play the key role in guiding economy to production of poultry products. Consumption of poultry depends upon the consumers income and prices of poultry products. The production of poultry meat in Bangladesh is 11500 MT (FAO, 2003). Availability of poultry meat in Bangladesh is only $16.5 \mathrm{~g} / \mathrm{d}$ (Amin, 2005), whereas world per capita consumption is $30.14 \mathrm{~g} / \mathrm{d}$ and $95.89 \mathrm{~g} / \mathrm{d}$ for USA (Farrell, 2003). Nutritional deficiency is very acute among the rural people for lack of animal protein. To reduce poverty and improve nutritional status poultry can play a significant role in the subsistence economy of rural people. It also provides income, high quality nutrition and self employment for unemployed men, women and youth. Poultry meat and eggs are superior to other types of meat for human consumption for its tenderness, palatability, digestibility and availability of amino acids. Supply of meat and egg are inadequate and beyond the purchasing capacity of general people. Poultry meat is very efficient and complete for the growth, development and maintenance of human health. Individuals of all ages are prescribed to consume poultry for quick health recovery during sickness. Poultry meat alone contributes $37 \%$ of the total meat production in the country and 22 to $27 \%$ of total animal protein (Ahmed, 1988 and Haque, 1992). Small scale poultry farming is important for rural families to meet up protein requirement and cash earning. The present experiment was undertaken to study pattern and problem of poultry consumption in rural and urban families. 


\section{Materials and Methods}

Study area: Study area was Fulbaria Upazila of Mymensingh district. Research area comprised of urban and rural. Urban area consists of some selected ward and rural comprises some selected villages adjacent and around Fulbaria Upazila.

Data collection: A total of 100 cross sectional families sampling units; 50 from urban and 50 from rural, were selected by stratified random sampling method. The pre-tested interview schedule designed contained both open and closed form of questions. Most easy, simple and direct questions were used to obtain information. The information on human health and nutrition, consumption of poultry meat and eggs and problem confrontation in consumption of poultry meat and eggs by the rural and urban people was collected.

Analysis of data: Quantitative collected data were complied, tabulated and analyzed. The statistical measurements used in describing the selected independent and dependent variables were range, mean, percentage, standard deviation and rank order. Coefficient of correlations ( $r$ ) was computed to have relations among variables.

\section{Results and Discussion}

\section{Characteristics of the consumers}

Average age of the respondents observed (44.62) coincide with Khanum (1997), but contradict (39.2) Rahman (2002). The differences could possibly be explained by the year and area of study. Literacy rate seemed to be higher in the rural area compared to that of urban area. Formal education in urban area found was lower than that of national average (BBS, 1999-2002). Formal education in rural area was higher than that of national average. Lower education rate among slum dwelling urban population may be the reason for decreasing formal education in urban area.

Family size: Family size ranged from 3 to 10 (Table 1) with an average of 6.68 which was greater than that of rural area (5.60). Bigger family of slum dwelling might have increased average family size in urban population. Family size of the respondents was higher than that of national average of 5.6 (BBS, 2001). Semi urbanization and urbanization nature of the study area may be responsible for this.

Table 1. Family size

\begin{tabular}{|c|c|c|c|c|c|c|c|c|c|c|c|}
\hline \multirow[t]{2}{*}{ Categories } & \multicolumn{3}{|c|}{ Urban } & \multicolumn{3}{|c|}{ Rural } & \multicolumn{3}{|c|}{ All area } & \multirow[t]{2}{*}{ Mean } & \multirow[t]{2}{*}{ SD } \\
\hline & $\begin{array}{c}\text { No of } \\
\text { Respondent }\end{array}$ & $\%$ & $\begin{array}{l}\text { Average } \\
\text { size }\end{array}$ & $\begin{array}{c}\text { No. of } \\
\text { Respondent }\end{array}$ & $\%$ & $\begin{array}{l}\text { Average } \\
\text { size }\end{array}$ & $\begin{array}{c}\text { No. of } \\
\text { Respondent }\end{array}$ & $\%$ & $\begin{array}{l}\text { Average } \\
\text { size }\end{array}$ & & \\
\hline Small (3-6) & 30 & 60 & \multirow{3}{*}{6.68} & 29 & 58 & \multirow{3}{*}{5.60} & 59 & 57 & \multirow{3}{*}{6.02} & \multirow{3}{*}{6.1} & \multirow{3}{*}{4.5} \\
\hline Medium (7-8) & 19 & 38 & & 18 & 36 & & 37 & 37 & & & \\
\hline $\begin{array}{l}\text { Large ( } 9 \text { and } \\
\text { above) }\end{array}$ & 1 & 2 & & 3 & 6 & & 4 & 4 & & & \\
\hline Total & 50 & & 100 & 50 & & 100 & 100 & & 100 & & \\
\hline
\end{tabular}

Farm size: Mean and standard deviation of the farm size was 200.89 and 188.1 decimal respectively (Table 2). Higher farm size in rural area than that of urban area may have been arisen for higher concentration of population and therefore, less availabilities of farming land in urban area. 
Table 2. Average land distribution

\begin{tabular}{|l|c|c|c|c|c|c|c|c|}
\hline \multirow{2}{*}{ Ownership pattern } & \multicolumn{2}{|c|}{ Urban } & \multicolumn{2}{c|}{ Rural } & \multicolumn{2}{c|}{ All area } & \multirow{2}{*}{ Mean } & \multirow{2}{*}{ SD } \\
\cline { 2 - 9 } & Decimal & $\%$ of total & Decimal & $\%$ of total & Decimal & $\%$ of total & & \\
\hline Land under own plough & 122.86 & 73.20 & 182.22 & 77.89 & 152.54 & 75.93 & & \\
\hline Own land but leased to other & 22.82 & 13.60 & 10.16 & 4.34 & 16.49 & 8.21 & & \\
\hline Leased from the other & 12.06 & 7.19 & 8.16 & 3.49 & 10.11 & 5.03 & 200.89 & 188.1 \\
\hline House land & 17.60 & 10.49 & 19.30 & 8.25 & 18.45 & 9.18 & & \\
\hline Pond area & 10.06 & 5.99 & 20.62 & 8.81 & 15.34 & 7.64 & & \\
\hline Uncultivated land & 5.56 & 3.91 & 9.80 & 4.19 & 8.18 & 4.07 & & \\
\hline Farm size & 137.84 & 100.00 & 233.94 & 100.00 & 200.89 & 100.00 & & \\
\hline
\end{tabular}

Livestock population: Livestock population of respondents ranged from 50 to 140, the average being 117.8 and standard deviation 101.5 (Table 3). Livestock population consisted $80 \%$ poultry and $20 \%$ large animal. According to (BBS, 1996) livestock population of Bangladesh consisted $77.44 \%$ poultry and $22.56 \%$ large animal which was higher in comparison with that of present study. The difference may be for variation of time and area.

Table 3. Distribution of the respondents according to their livestock population

\begin{tabular}{|l|c|c|c|c|c|c|}
\hline \multirow{2}{*}{ Categories } & \multicolumn{2}{|c|}{ Urban } & \multicolumn{2}{c|}{ Rural } & \multirow{2}{*}{ SD } \\
\cline { 2 - 6 } & Respondent no. & $\%$ & Respondent no. & $\%$ & & \\
\hline Low (50-110) & 35 & 70 & 40 & 80 & & \\
\hline Medium (111-135) & 10 & 20 & 9 & 18 & 117.8 & 101.5 \\
\hline Large (136 and above) & 5 & 10 & 1 & 2 & & \\
\hline Total & 50 & 100 & 50 & 100 & & \\
\hline
\end{tabular}

Family education: Family education ranged from 0 to 16 with an average 5.3 and standard deviation 2.9 (Table 4). Lack of education among the slum dwelling population might have decreased average education rate in urban area.

Table 4. Education level of family member of the respondents

\begin{tabular}{|l|c|c|c|c|c|c|c|c|}
\hline \multirow{2}{*}{ Education level } & \multicolumn{2}{|c|}{ Urban } & \multicolumn{2}{c|}{ Rural } & \multicolumn{2}{c|}{ All area } & \multirow{2}{*}{ Mean } \\
\cline { 2 - 9 } & $\begin{array}{c}\text { No. of } \\
\text { member }\end{array}$ & $\%$ & $\begin{array}{c}\text { No. of } \\
\text { member }\end{array}$ & $\%$ & $\begin{array}{c}\text { No. of } \\
\text { member }\end{array}$ & $\%$ & & \\
\hline No education & 37 & 17.96 & 13 & 10.00 & 50 & 14.93 & & \\
\hline Can sign only & 30 & 14.56 & 20 & 15.50 & 50 & 14.93 & & \\
\hline $\begin{array}{l}\text { Do not go to and school but can read } \\
\text { and write }\end{array}$ & 20 & 9.71 & 8 & 6.20 & 28 & 4.36 & 5.3 & 2.9 \\
\hline Primary education (1-5) & 47 & 22.82 & 25 & 19.38 & 72 & 21.49 & & \\
\hline Secondary (6-10) & 54 & 26.21 & 48 & 37.21 & 102 & 30.45 & & \\
\hline Above secondary (11 and above) & 18 & 8.74 & 15 & 11.63 & 33 & 9.85 & & \\
\hline Total & 129 & 100 & 206 & 100 & 335 & 100 & & \\
\hline
\end{tabular}

Income: Crop contributed $58 \%$ and $38 \%$ to total income in rural and urban area respectively. Cattle shared $10 \%$ and $12 \%$ of total income in rural and urban area. Poultry contributed $4 \%$ and $3 \%$ to total income rural and urban areas respectively (Table 5). Annual income observed seems to be lower than that reported Khanun (1997) at Muktagacha. The difference may be for more business community living at Muktagacha powroshava. 
Table 5. Annual household income

\begin{tabular}{|l|c|c|c|c|c|c|c|c|}
\hline \multirow{2}{*}{ Sources } & \multicolumn{2}{|c|}{ Urban } & \multicolumn{2}{c|}{ Rural } & \multicolumn{2}{c|}{ All area } & \multirow{2}{*}{ Mean } & \multirow{2}{*}{ SD } \\
\cline { 2 - 8 } & Taka & $\%$ share & Taka & \% share & Taka & \% share & & \\
\hline Crop & 17790 & 58 & 16940 & 38 & 17365 & 46 & & \\
\hline Cattle & 3120 & 10 & 5840 & 13 & 4480 & 12 & \\
\hline Poultry & 902 & 3 & 1632 & 4 & 1267 & 3 & \multirow{3}{*}{37751} & \multirow{2}{*}{28584} \\
\hline Fisheries & 1368 & 4 & 4250 & 9 & 2809 & 7 & \\
\hline Business & 4640 & 15 & 7860 & 18 & 6250 & 17 & & \\
\hline Other & 2780 & 9 & 8380 & 19 & 5580 & 15 & & \\
\hline Total & 30600 & 100 & 44902 & 100 & 37751 & 100 & & \\
\hline
\end{tabular}

\section{Knowledge on health and nutrition}

Knowledge on health and nutrition of the respondents was ranged from 5-34 with an average of 20.8 and standard deviation 3.0. Urban people have more knowledge on health and nutrition than that among rural area people (Table 6). Knowledge on health and nutrition recorded is lower than that observed (47\%) by Rahman (2002) in rural areas of Mymensingh sadar.

Table 6. Knowledge of health and nutrition

\begin{tabular}{|l|c|c|c|c|c|c|c|c|}
\hline \multirow{2}{*}{ Categories } & \multicolumn{2}{|c|}{ Urban } & \multicolumn{2}{c|}{ Rural } & \multicolumn{2}{c|}{ All area } & \multirow{2}{*}{ Mean } \\
\cline { 2 - 8 } & $\begin{array}{c}\text { No. of } \\
\text { respondent }\end{array}$ & $\%$ & $\begin{array}{c}\text { No. of } \\
\text { respondent }\end{array}$ & $\%$ & $\begin{array}{c}\text { No. of } \\
\text { respondent }\end{array}$ & $\%$ & & \\
\hline Poor (5-15) & 25 & 50 & 35 & 70 & 60 & 60 & & \\
\hline Moderate (16-25) & 15 & 30 & 10 & 20 & 25 & 25 & 20.8 & 3.0 \\
\hline High (26 and above) & 10 & 20 & 5 & 10 & 15 & 15 & & \\
\hline Total & 50 & 100 & 50 & 100 & 100 & 100 & & \\
\hline
\end{tabular}

\section{Consumption of poultry by the respondents}

The consumption score of poultry among the respondents ranged from 1.88 to 70 , with an average of 15.0 and standard deviation 17.6 (Table 7).

Table 7. Distribution of respondents according to consumption of poultry

\begin{tabular}{|c|c|c|c|c|c|c|c|c|}
\hline \multirow[t]{2}{*}{ Categories } & \multicolumn{2}{|c|}{ Urban } & \multicolumn{2}{|c|}{ Rural } & \multicolumn{2}{|c|}{ All area } & \multirow[t]{2}{*}{ Mean } & \multirow[t]{2}{*}{ SD } \\
\hline & $\begin{array}{c}\text { No. of } \\
\text { response }\end{array}$ & $\%$ & $\begin{array}{c}\text { No. of } \\
\text { response }\end{array}$ & $\%$ & $\begin{array}{c}\text { No. of } \\
\text { response }\end{array}$ & $\%$ & & \\
\hline Poor (up to 20) & 25 & 50 & 30 & 60 & 55 & 55 & & \\
\hline Medium (20.01-41.00) & 20 & 40 & 15 & 30 & 25 & 35 & 15.0 & 17.6 \\
\hline High (41.01and above) & 5 & 10 & 5 & 10 & 10 & 10 & & \\
\hline Total & 50 & 100 & 50 & 100 & 100 & 100 & & \\
\hline
\end{tabular}

Poultry consumption in both rural and urban area is not satisfactory. Possibly for lack in knowledge on nutrition, they do not know how the poultry products are useful to uplift nutritional status. Poor purchasing ability may be an additional reason. 


\section{Problem of the respondents in consumption of poultry}

Consumption problems for the urban respondents: Problem confrontation index $(\mathrm{PCl})$ of the urban families on 11 items in consumption problem ranged from 27 to 143 against a possible range of 0 to 150 . $\mathrm{PCl}$ of 4 problem exceeded 100 and 2 problems were having $\mathrm{PCl}$ over 90 . However, the top 4 problems were nonavailability of day old chicks, insufficient supply of feed for crises of money, nonavailability of balanced diet in appropriate time and fluctuating and nonsured prices of egg and meat. Above facts indicate a tremendous need for modern family poultry programmes to be launched by the DLS and other agencies to uplift their income and nutritional status.

\section{Consumption problems for the rural respondents:}

\section{Table 8. Consumption problems for the rural family members}

\begin{tabular}{|c|l|c|c|c|c|c|}
\hline \multicolumn{1}{|c|}{$\begin{array}{c}\text { Sl. Item of problem } \\
\text { No. }\end{array}$} & \multicolumn{2}{|c|}{ Frequency of problem } & \multirow{2}{*}{ Index } & Rank \\
\cline { 3 - 5 } & & High & Average & Not at all & & \\
\hline 1. & Day old chicks are not available in appropriate time & 42 & 3 & 2 & 138 & 1 \\
\hline 2. & $\begin{array}{l}\text { Supply of optimum amount of feed for poultry is not possible } \\
\text { due to the crises of money }\end{array}$ & 33 & 11 & 6 & 121 & 2 \\
\hline 3. & Balanced diets are not available in appropriate time & 12 & 35 & 3 & 106 & 3 \\
\hline 4. & Due prices of egg and meat are not assured & 14 & 32 & 2 & 106 & 4 \\
\hline 5. & Medicines are not available in due price & 18 & 24 & 8 & 102 & 5 \\
\hline 6. & Food values of meat and egg are not known & 5 & 41 & 4 & 97 & 6 \\
\hline 7. & Enough knowledge are not available in hybrid poultry rearing & 2 & 42 & 6 & 90 & 7 \\
\hline 8. & Correct techniques are not known in vaccination & 5 & 27 & 18 & 69 & 8 \\
\hline 9. & Chickens are died in contagious disease & 0 & 29 & 19 & 58 & 9 \\
\hline 10. & Labourers are not available in appropriate time & 0 & 20 & 30 & 40 & 10 \\
\hline 11. & Poultry vaccines are not available in appropriate time & 1 & 15 & 34 & 33 & 11 \\
\hline
\end{tabular}

Perhaps for staying side by side consumption problems were similar in rural and urban areas.

\section{Overall consumption problems by all respondents:}

Table 9. Overall consumption problem

\begin{tabular}{|c|l|c|c|c|c|c|}
\hline $\begin{array}{c}\text { Sl. } \\
\text { No. }\end{array}$ & \multicolumn{1}{|c|}{ Item of problem } & \multicolumn{2}{c|}{ Frequency of problem } & Index & Rank \\
\hline & \multicolumn{1}{|c|}{} & \multicolumn{1}{|c|}{ High } & Average & Not at all & & \\
\hline 1. & Day old chicks are not available in appropriate time & 87 & 10 & 3 & 281 & 1 \\
\hline 2. & $\begin{array}{l}\text { Supply of optimum amount of feed for poultry is not possible } \\
\text { due to the crises of money }\end{array}$ & 75 & 16 & 9 & 257 & 2 \\
\hline 3. & Balanced diets are not available in appropriate time & 35 & 59 & 6 & 223 & 3 \\
\hline 4. & Due prices of egg and meat are not assured & 43 & 48 & 9 & 219 & 4 \\
\hline 5. & Food values of meat and egg are not known & 14 & 76 & 10 & 194 & 5 \\
\hline 6. & Medicines are not available in due price & 33 & 47 & 20 & 193 & 6 \\
\hline 7. & $\begin{array}{l}\text { Enough knowledge are not available in hybrid poultry } \\
\text { rearing }\end{array}$ & 9 & 76 & 15 & 179 & 7 \\
\hline 8. & Correct techniques are not known in vaccination & 21 & 39 & 40 & 141 & 8 \\
\hline 9. & Chickens are died in contagious disease & 5 & 65 & 30 & 136 & 9 \\
\hline 10. & Labourers are not available in appropriate time & 5 & 30 & 65 & 75 & 10 \\
\hline 11. & Poultry vaccines are not available in appropriate time & 2 & 27 & 71 & 60 & 11 \\
\hline
\end{tabular}


Overall problem confrontation index $(\mathrm{PCl})$ of urban and rural families on 11 item in consumption problem ranged from 60 to 281 against possible range of 0 to $300 . \mathrm{PCl}$ of the four problems exceeded 200 and five problems were having $\mathrm{PCl}$ over 100 . The average families both in rural and urban area live within massive poverty and have little cash. The veterinary assistance is hardly available to the people for healthy poultry and cattle. The people mostly rear poultry as small flock of 10 birds. But there are a few number rear poultry as commercially with 500 to 1000 birds. Veterinary medicines are sold in high price. The extension agencies have no specific programme on modern poultry farming.

\section{Relationships among variables}

The correlation coefficients of 8 selected independent and 2 selected dependent variables; consumption of poultry and problem confrontation in consumption by the rural and urban respondents are presented in Table 10 and11.

Table 10. Correlation coefficients analysis among independent and dependent variable incase of urban respondents

\begin{tabular}{|c|l|c|c|}
\hline Sl. & \multicolumn{1}{|c|}{ Independent variable } & \multicolumn{2}{c|}{ Dependent variable } \\
\cline { 3 - 4 } No. & & $\begin{array}{c}\text { Consumption of poultry } \\
\text { by urban respondents }\end{array}$ & $\begin{array}{c}\text { Problem in consumption of } \\
\text { poultry by urban respondents }\end{array}$ \\
\hline 1. & Age & $0.85^{\star \star}$ & $-0.84^{\star \star}$ \\
\hline 2. & Level of education & $0.23 \mathrm{NS}$ & $-0.24 \mathrm{NS}$ \\
\hline 3. & Family size & $-0.42^{\star}$ & $0.86^{\star \star}$ \\
\hline 4. & Farm size & $0.63^{\star \star}$ & $-0.24 \mathrm{NS}$ \\
\hline 5. & Livestock population & $0.49^{\star}$ & $-0.21 \mathrm{NS}$ \\
\hline 6. & Family education & $0.37 \mathrm{NS}$ & $-0.25 \mathrm{NS}$ \\
\hline 7. & Income & $0.52^{\star}$ & $-0.23 \mathrm{NS}$ \\
\hline 8. & Knowledge on health and nutrition & $0.85^{\star \star}$ & $-0.55^{\star}$ \\
\hline
\end{tabular}

NS, $p>0.05 ;{ }^{*}, p<0.05 ;{ }^{* *}, p<0.01$

Table 11. Correlation coefficients analysis among independent and dependent variable incase of rural respondents

\begin{tabular}{|c|l|c|c|}
\hline SI. & \multicolumn{1}{|c|}{ Independent variable } & \multicolumn{2}{|c|}{ Dependent variable } \\
\cline { 3 - 4 } No. & & $\begin{array}{c}\text { Consumption of poultry } \\
\text { by rural respondents }\end{array}$ & $\begin{array}{c}\text { Problem in consumption of } \\
\text { poultry by rural respondents }\end{array}$ \\
\hline 1. & Age & $0.61^{*}$ & $0.22 \mathrm{NS}$ \\
\hline 2. & Level of education & $0.50^{*}$ & $-0.28 \mathrm{NS}$ \\
\hline 3. & Family size & $-0.38 \mathrm{NS}$ & $0.21 \mathrm{NS}$ \\
\hline 4. & Farm size & $0.43^{*}$ & $-0.30 \mathrm{NS}$ \\
\hline 5. & Livestock population & $0.52^{*}$ & $-0.51^{*}$ \\
\hline 6. & Family education & $0.34 \mathrm{NS}$ & $-0.23 \mathrm{NS}$ \\
\hline 7. & Income & $0.42^{*}$ & $-0.44^{*}$ \\
\hline 8. & Knowledge on health and nutrition & $0.69^{* *}$ & $-0.38 \mathrm{NS}$ \\
\hline & & & \\
\hline
\end{tabular}

NS, $p>0.05 ;{ }^{*}, p<0.05 ;{ }^{* *}, p<0.01$

In urban area age, farm size, livestock population, income and knowledge on health and nutrition had a significant positive while family size had significant negative correlations with poultry consumption. Age, family size and knowledge on health and nutrition had significant negative correlations with problem confrontation (Table 10). In rural area age, level of education, farm size, livestock population, income and knowledge on health and nutrition maintained significant positive correlations with poultry consumption, while livestock 
population and income had significant negative correlations with problem confrontation (Table 11).

Hai et al.

A positive correlation of age with poultry consumption implies that per capita poultry consumption is higher for older people. Reverse case is expected to build a healthy society. From correlations it can be concluded that in urban area increased farm size, increased livestock population, increased income, better knowledge on health and nutrition and decreased family size should increase per capita poultry consumption. Correlations also indicate that decreased family size and better knowledge on health and nutrition could minimize problems of poultry consumption. In rural area correlations computed impress that increased literacy, increased farm size, increased livestock population, increased income and better knowledge on health and nutrition should increase per capita poultry consumption. Whereas, increased income could remove problems of poultry consumption.

\section{References}

Ahmed, S. 1988. Role of farming system research in identification of problems of poultry production. Proceedins of the workshop of livestock component of Farming system Research in Bangladesh. $21^{\text {st }}$ December, 1988. Bangladesh Agricultural Research Council, Dhaka, Bangladesh.

Amin, M.N. 2005. The participation of highly educated unemployed persons in the poultry industry in Bangladesh: Prospect and Proposals in Bangladesh. Poultry Khamar Bichitra. 13 (11): 41-46.

BBS (Bangladesh Bureau of Statistics). 2001. Statistical Yearbook of Bangladesh. Stat. Div. Minis. Planning. Govt. People's Repub. Bangladesh, Dhaka.

BBS (Bangladesh Bureau of Statistics). 1999-2002. Statistical Yearbook of Bangladesh. Stat. Div. Minis. Planning. Govt. People's Repub. Bangladesh, Dhaka.

BBS (Bangladesh Bureau of Statistics). 1996. Statistical Yearbook of Bangladesh. Stat. Div. Minis. Planning. Govt. People's Repub. Bangladesh, Dhaka.

FAO (Food and Agriculture Organization). 2003. FAO Yearbook Production. Food and Agriculture Organization of the United Nations, Rome, Italy. 57: 223.

Farrell, D. 2003. Status of Poultry in global food production, special emphasis on the Asian Pacific Region. Proceedings of $3^{\text {rd }}$ World Poultry Show and Seminar, WAPSA (Bangladesh Branch), Dhaka.

Haque, Q.M.E. 1992. Rural poultry in Bangladesh Economy. Proceedings of $4^{\text {th }}$ National Conference of Bangladesh Animal Husbandry Association, Held on December 1992, Dhaka.

Khanun, H. 1997. Consumer attitude towards poultry and poultry products in Muktagacha Powroshava of Mymensingh district. M.S. thesis, Department of Poultry Science, Bangladesh Agricultural University, Mymensingh.

Rahman, M.W. 2002. Consumption of poultry and poultry products by the rural families in selected villages of sadar upazila under Mymensingh. M.S. thesis, Department of Poultry Science, Bangladesh Agricultural University, Mymensingh. 